\title{
Pharmacological Blockade of $5-\mathrm{HT}_{7}$ Receptors as a Putative Fast Acting Antidepressant Strategy
}

\author{
Ouissame Mnie-Filali ${ }^{1,4}$, Céline Faure ${ }^{1,4}$, Laura Lambás-Señas' ${ }^{1,5}$, Mostafa El Mansari ${ }^{2}$, Hassina Belblidia', \\ Elise Gondard', Adeline Etiévant', Hélène Scarna' ${ }^{1,5}$, Anne Didier ${ }^{3}$, Anne Berod', Pierre Blier $^{2}$ \\ and Nasser Haddjeri ${ }^{1,5}$
}

'Université de Lyon, Université Claude Bernard Lyon I, Faculty of Pharmacy, Laboratoire de Neuropharmacologie, CNRS EAC 5006, Lyon, France; ${ }^{2}$ Institute of Mental Health Research, University of Ottawa, Canada; ${ }^{3}$ Laboratoire de Neurosciences et Systèmes Sensoriels, CNRS UMR 5020, Université Claude Bernard-Lyon I, Lyon, France

Current antidepressants still display unsatisfactory efficacy and a delayed onset of therapeutic action. Here we show that the pharmacological blockade of serotonin $7\left(5-\mathrm{HT}_{7}\right)$ receptors produced a faster antidepressant-like response than the commonly prescribed antidepressant fluoxetine. In the rat, the selective 5- $\mathrm{HT}_{7}$ receptor antagonist SB-269970 counteracted the anxiogenic-like effect of fluoxetine in the open field and exerted an antidepressant-like effect in the forced swim test. In vivo, 5- $\mathrm{HT}_{7}$ receptors negatively regulate the firing activity of dorsal raphe $5-\mathrm{HT}$ neurons and become desensitized after long-term administration of fluoxetine. In contrast with fluoxetine, a I-week treatment with SB-269970 did not alter 5-HT firing activity but desensitized cell body 5-HT autoreceptors, enhanced the hippocampal cell proliferation, and counteracted the depressive-like behavior in olfactory bulbectomized rats. Finally, unlike fluoxetine, early-life administration of SB-269970, did not induce anxious/depressive-like behaviors in adulthood. Together, these findings indicate that the $5-\mathrm{HT}_{7}$ receptor antagonists may represent a new class of antidepressants with faster therapeutic action.

Neuropsychopharmacology (201 I) 36, 1275-1288; do::10.1038/npp.201 I. I3; published online 16 February 201 I

Keywords: mood; anxiety; 5-HT receptors; antidepressant; dorsal raphe; neurogenesis

\section{INTRODUCTION}

There are extensive data demonstrating the involvement of the brain serotonin (5-HT) system in both the pathogenesis of depression and the action of antidepressant (AD) drugs. However, optimal therapeutic effectiveness is not achieved with current ADs, because most agents present major drawbacks in clinical use, such as a delayed onset of their action and a high percentage of non-responders. Selective 5-HT reuptake inhibitors (SSRIs) exert their actions by enhancing synaptic availability of 5-HT. However, a series of neuroadaptive changes must first occur for this to happen, and these changes are thought to underlie the prolonged therapeutic latency of these drugs (Blier and de Montigny, 1999; Duman et al, 2001; Nestler et al, 2002). Examples of the above mentioned changes include a progressive desensitization of raphe $5-\mathrm{HT}_{1 \mathrm{~A}}$ autoreceptors

Correspondence: Dr N Haddjeri, University Claude Bernard Lyon I, Faculty of Pharmacy, Laboratory of Neuropharmacology, CNRS EAC 5006, 8 avenue Rockefeller, Lyon, F-69373, France.

Tel: + (33) 4266882 15, Fax: + (33) $4787772-09$,

E-mail: nasser.haddjeri@univ-lyon I.fr

${ }^{4}$ These authors contributed equally to this work.

${ }^{5}$ INSERM employee.

Received 3 November 2010; revised 4 January 2011; accepted 6 January 2011 and a stimulation of the cell proliferation in the dentate gyrus (DG) of the hippocampus following long-term treatment with SSRIs, with a time course consistent with their delayed AD effects (Blier and de Montigny, 1999; Hensler, 2002; Santarelli et al, 2003; Castrén, 2004; Lanfumey and Hamon, 2004; Faure et al, 2006a).

Recently, attention has been given to $5-\mathrm{HT}_{7}$ receptors because of their potential role in mood disorders including depression (for reviews, see Hedlund, 2009 and Mnie-Filali et al, 2009). The $5-\mathrm{HT}_{7}$ receptor is the most recently identified member of the 5HT receptor family and has been cloned from several species including humans (Hedlund and Sutcliffe, 2004). The 5- $\mathrm{HT}_{7}$ receptors have been shown to be involved in various functions modulated by the 5-HT system such as circadian rhythms and thermoregulation (Thomas et al, 2003; Hedlund et al, 2004; Faure et al, 2006b). Moreover, $5-\mathrm{HT}_{7}$ receptors in the hippocampal formation also seem to be involved in interactions between 5-HT system and the hypothalamic-pituitary-adrenal axis (Yau et al, 2001; Laplante et al, 2002). In addition, the localization of $5-\mathrm{HT}_{7}$ receptors in corticolimbic areas related to affective processes and their involvement in functions impaired in depressed patients suggest an important role of these receptors in mood disorders (Ruat et al, 1993; To et al, 1995; Mnie-Filali et al, 2007a, 2009). More direct evidence, such as downregulation of $5-\mathrm{HT}_{7}$ receptors in hypothalamus after chronic AD treatments (Sleight et al, 1995; Mullins et al, 1999) 
and antidepressant-like behaviors produced by $5-\mathrm{HT}_{7}$ receptor knock-out mice (Hedlund et al, 2005; Guscott et al, 2005) strengthen this hypothesis.

In this study, the $\mathrm{AD}$ potential of the selective $5-\mathrm{HT}_{7}$ receptor antagonist SB-269970 was first assessed using the forced swim test (FST) in rats. Then, we investigated whether only a 1-week treatment with SB-269970 is able to elicit the same functional and cellular changes as those induced by classical ADs, including desensitization of dorsal raphe nucleus (DRN) 5- $\mathrm{HT}_{1 \mathrm{~A}}$ autoreceptors, enhanced inhibitory tone mediated by postsynaptic $5-\mathrm{HT}_{1 \mathrm{~A}}$ receptors in the hippocampus, and the stimulation of hippocampal cell proliferation. The effects of SB-269970 were compared with those induced by 1 -week treatment with the widely used SSRI fluoxetine. The action of SB-269970 and fluoxetine was then assessed in the olfactory bulbectomy (OBX) paradigm, considered as a 'chronic' behavioral model of depression in which classical $\mathrm{AD}$ treatments require the administration for 2-3 weeks before any AD-like effects can be observed (Song and Leonard, 2005). Finally, the potential of SB-269970 to produce, like fluoxetine, anxious- and/or depressive-like effects following early life exposure was examined.

\section{MATERIALS AND METHODS}

\section{Animals}

Experiments were carried out in male Sprague-Dawley rats weighing 250-300 g (Harlan (Gannat, France) or Charles River (Saint-Constant, QC, Canada)). Animals were kept under standard laboratory conditions (12-h light:12-h dark cycle) with free access to food and water. They were habituated at least 1 week to the laboratory facility before each experiment. Experiments were in accordance to the European Communities Council Directives 86/609, OJ L 358,1, 12 December, 1987, for the care and use of laboratory animals. Also, the electrophysiological experiments performed in Canada were approved by the local Animal Care Committee and were in accordance with the guidelines set by the Canadian Council for Animal Care.

\section{Drugs}

SB-269970 ((R)-3-(2-(2-(4-methyl-piperidin-1-yl)ethyl)-pyrrolidine-1-sulphonyl)-phenol), AS19 ((2S)-(+)-5-(1,3,5-trimethylpyrazol-4-yl)-2-(dimethylamino)tetralin), and paroxetine were obtained from TOCRIS (Illkirch, France). L-5-HTP (L-5-Hydroxytryptophan), PCPA parachlorophenylalanine, WAY-100635 (N-(2-(4(2-methoxyphenyl)-1-piperazinyl) ethyl) -N-(2-pyridinyl) cyclohexanecarboxamide trihydrochloride), 8-OH-DPAT (8-hydroxy-2-(di-n-propylamino)tetralin), and BrdU (5-Bromo3 'deoxyuridine) were purchased from Sigma Aldrich (StQuentin Fallavier, France). Fluoxetine was obtained from LKT Laboratories (St Paul, MN, USA).

\section{Open-Field Test}

Open field was performed in a white wooden chamber $(100 \times 100 \times 40 \mathrm{~cm})$. Testing took place under bright ambient light conditions (400lux) to increase the anxiety component of the center area of the open field. Rats were intraperitoneally injected with the vehicle (water) (vehicle and SB-269970 groups) or fluoxetine $(10 \mathrm{mg} / \mathrm{kg})$ (fluoxetine and fluoxetine + SB-269970 groups) $1 \mathrm{~h}$ before the test and then with the vehicle (vehicle and fluoxetine groups) or SB-269970 (2 mg/kg) (SB-269970 and fluoxetine + SB269970 groups) 30 min later. Each rat was then placed in a corner of the open field and allowed to explore freely for $5 \mathrm{~min}$. Exploratory activity was monitored by a video camera fixed above the arena and relayed to a computer system. Anxiety-like behavior was assessed as the number of visits to the center area of the open field (defined as the central of $60 \times 60 \mathrm{~cm}$ portion) over a $5 \mathrm{~min}$ period.

\section{FST}

The FST was used as previously described (Porsolt et al, 1977 ) to evaluate potential AD effects. Briefly, rats experienced a pre-test session followed $24 \mathrm{~h}$ later by a test session. For both the pre-test and the test sessions, conducted under low illumination (12lux), the rats were placed in a plastic cylindrical tank $(50 \mathrm{~cm}$ high by $20 \mathrm{~cm}$ in diameter) filled with water at $23 \pm 2{ }^{\circ} \mathrm{C}$, with a depth of $40 \mathrm{~cm}$, for which the hind limbs could not reach the tank floor. In all experiments, the pre-test was carried out for $15 \mathrm{~min}$ and the test for $6 \mathrm{~min}$ in the same tank. Vehicle (water) or SB-269970 (0.5 mg/kg, i.p.) was administered between these two sessions $(23,5$, and $1 \mathrm{~h}$ before the test sessions). Following either pre-test or test sessions, rats were dried with a towel and kept warm for $30 \mathrm{~min}$ before returning to their home cage. A camera coupled with a computer recorded the behavior of the animal online during the FST and the immobility duration was then assessed by image analysis through a specialized digital interface (Videotrack, ViewPoint, Lyon, France) as previously described by Haddjeri et al. (2004). Software from ViewPoint permitted us to analyze data offline avoiding observer subjectivity.

\section{Locomotor Activity}

These experiments were performed in order to ensure that behaviors in the FST were not secondary to a nonspecific alteration in locomotor activity produced by the treatments. In order to simulate the treatment procedure used in the FST, rats were injected with vehicle (water) or SB-269970 $(0.5 \mathrm{mg} / \mathrm{kg}$, i.p.) three times within 24 hours: $23 \mathrm{~h}, 5 \mathrm{~h}$, and $1 \mathrm{~h}$ before the test. They were then placed in activity cages in an actimeter (Imetronic, France) equipped with two infrared beams (one at the front and one at the back) positioned $4 \mathrm{~cm}$ above the floor. Locomotor activity was estimated by the determination of successive beam breaks at the front and at the back, and vice versa (crossovers) during a $10-$ min session.

\section{Head-Twitch Response (HTR)}

The global design of these experiments was chosen on the basis of previous work of Sánchez and Kreilgaard (2004). Thirty minutes after drugs or vehicle (saline or polyethylene glycol 5\% for AS19) injection, the rats were given L-5-HTP $(87.3 \mathrm{mg} / \mathrm{kg}$, s.c.). Each animal was then placed in an observation cage and the cumulative number of head twitches (which consists of a characteristic, rapid and rotational 
flick of the head, ears, and neck) was counted during 10 min. Assessments were performed by observers blind to the drug condition of rats.

\section{Extracellular Unitary Recordings of DRN 5-HT Neurons}

Extracellular unitary recordings of DRN 5-HT neurons were performed in chloral hydrate anesthetized rats $(400 \mathrm{mg} / \mathrm{kg}$, i.p.), with single-barrelled glass micropipettes positioned $1 \mathrm{~mm}$ anterior to lambda on the midline (Haddjeri and Blier, 1995). Presumed DRN 5-HT neurons were identified using the criteria of Aghajanian and Vandermaelen (1982), ie a slow $(0.5-2.5 \mathrm{~Hz})$ and regular firing rate and longduration (0.8-1.2 ms) positive action potentials. For drug administration, a baseline firing rate was established over $1-2 \mathrm{~min}$ and the 5- $\mathrm{HT}_{7}$ agonist AS19 (dissolved in polyethylene glycol $5 \%$ ) at a dose of $2.5-10 \mathrm{mg} / \mathrm{kg}$ was intravenously injected in 1-2-min intervals until cell firing was completely suppressed with or without prior injection (2-3 min) of SB-269970 (0.1 mg/kg, i.v. dissolved in saline) as well as in rats pre-treated for 15 days with fluoxetine (10 $\mathrm{mg} / \mathrm{kg}$ per day, i.p. dissolved in saline). In each rat, only one neuron was studied.

For the chronic studies, in order to determine the possible changes of the spontaneous firing activity of dorsal raphe 5-HT neurons, rats were injected daily for 1 week with fluoxetine $(10 \mathrm{mg} / \mathrm{kg}$, i.p. dissolved in saline) or SB-269970 ( $2 \mathrm{mg} / \mathrm{kg}$, i.p. dissolved in saline). Four to five electrode descents were carried out through this nucleus about $1 \mathrm{~h}$ after the last i.p. injection. Finally, the responsiveness of 5-HT neurons to enhanced 5-HT levels was evaluated by using the SSRI paroxetine $(0.5 \mathrm{mg} / \mathrm{kg}$, i.v.) in control and treated rats for 1 week with SB-269970 (2 mg/kg, i.p.). The percentage of inhibition of cell firing (\% of inhibition) was calculated by comparison of the mean baseline firing obtained from a 1-2 min interval before the initial drug application and the mean cell firing rate obtained from a 1-2 min interval following each drug injection.

\section{Recordings from Dorsal Hippocampus CA3 Pyramidal Neurons}

Rats received a daily injection of vehicle (saline), fluoxetine (10 mg/kg, i.p.), or SB-269970 (2 mg/kg, i.p.) for 1 week. Recording and microiontophoresis were performed with five-barreled glass micropipettes broken back to $8-12 \mu \mathrm{M}$ under microscopic control. The central barrel was filled with a $2 \mathrm{M} \mathrm{NaCl}$ solution and used for extracellular unitary recordings. Pyramidal neurons were identified by their large amplitude $(0.5-1.2 \mathrm{mV})$ and long-duration (0.8-1.2 ms) simple spikes alternating with complex spike discharges (Kandel and Spencer, 1961). The side barrels contained the following solutions: 5 -HT creatinine sulfate $(2 \mathrm{mM}$ in $200 \mathrm{mM} \mathrm{NaCl}, \mathrm{pH} \mathrm{4}$ ), quisqualate $(1.5 \mathrm{mM}$ in $200 \mathrm{mM} \mathrm{NaCl}$, $\mathrm{pH} 8$ ), and $2 \mathrm{M} \mathrm{NaCl}$ used for automatic current balancing. The rats were mounted in a stereotaxic apparatus and the microelectrodes were lowered at $4.2 \mathrm{~mm}$ lateral and $4.2 \mathrm{~mm}$ anterior to lambda into the CA3 region of the dorsal hippocampus. As most hippocampus pyramidal neurons are not spontaneously active under chloral hydrate anesthesia, a leak or a small ejection current of quisqualate $(+2$ to $-8 \mathrm{nA})$ was used to activate them within their physiological firing range (10-15 Hz; Ranck, 1975). A 10 or $20 \mathrm{nA}$ ejection current of 5-HT was used, each ejection period lasting $50 \mathrm{~s}$. In order to assess the degree of activation of the postsynaptic $5-\mathrm{HT}_{1 \mathrm{~A}}$ receptors exerting an inhibitory influence on the firing activity of CA3 pyramidal neurons, WAY 100635 was administered intravenously to disinhibit the hippocampal neurons resulting in an increase of their firing activity. The saline injection corresponds to the $0 \mathrm{mg} / \mathrm{kg}$ dose. WAY 100635 was administered in incremental doses of $25 \mu \mathrm{g} / \mathrm{kg}$ at time intervals of $2 \mathrm{~min}$. To avoid residual drug effects, only one cell was studied in each rat. The change of firing activity was assessed by calculating the mean firing rate of neurons from about 1-2 min before and after (until a 'plateau') the i.v. administration of the drugs and the percent of change was calculated.

\section{Cell Proliferation in the Subgranular and the Subventricular Zones}

As previously described (Mnie-Filali et al, 2007b), rat hippocampal cell proliferation was evaluated after seven daily injections with saline, fluoxetine $(10 \mathrm{mg} / \mathrm{kg}$, i.p.), or SB-269970 (2 mg/kg, i.p.). A group of rats treated with SB-269970 received a daily administration of PCPA $(400 \mathrm{mg} / \mathrm{kg}$, i.p.) during the last 3 pretreatment days. On the sixth day, all the groups of rats received four injections of BrdU ( $50 \mathrm{mg} / \mathrm{kg}$, i.p.) separated by $2 \mathrm{~h}$ intervals. Twenty-four hours after the last BrdU injection, animals were deeply anesthetized and transcardially perfused with $\mathrm{NaCl} 0.9 \%$ for $5 \mathrm{~min}$ followed by $4 \%$ cold formaldehyde in phosphate buffer (PB: $0.1 \mathrm{M}, \mathrm{pH} 7.4$ ) for $17 \mathrm{~min}$. The brains were then removed, post-fixed overnight in formaldehyde and stored at $4{ }^{\circ} \mathrm{C}$ in $30 \%$ sucrose. The $30 \mu \mathrm{m}$ coronal sections were cut through the olfactory bulb or the hippocampus, (respectively from +2.28 to $-0.48 \mathrm{~mm}$ and from -1.8 to $-5.8 \mathrm{~mm}$, posterior to bregma, according to Paxinos and Watson, 1998) collected as a series of 12 serial sections and stored in phosphate buffer saline (PBS) containing $0.1 \%$ of sodium azide at $4{ }^{\circ} \mathrm{C}$. These free-floating sections were used in the determination of BrdU labeling. DNA denaturation was conducted by incubation for $2 \mathrm{~h}$ in $50 \%$ formamide $/ 2 \times$ SSC $\left(0.3 \mathrm{M} \mathrm{NaCl}, 0.003 \mathrm{M}\right.$ sodium citrate) at $65^{\circ} \mathrm{C}$ followed by two rinses in $2 \times$ SCC buffer. Sections were incubated for $30 \mathrm{~min}$ in $\mathrm{HCl}(2 \mathrm{~N})$ and then $10 \mathrm{~min}$ in borate buffer (0.1 M, pH 8). All incubations were followed by three rinses of $10 \mathrm{~min}$ in PBST (PBS $+0.1 \%$ Triton X-100) at room temperature. Sections were processed for $3 \mathrm{~min}$ on pepsin $(0.45 \mathrm{U} / \mathrm{ml}$ in $0.1 \mathrm{~N} \mathrm{HCl})$ and transferred for $15 \mathrm{~min}$ onto $3 \%$ $\mathrm{H}_{2} \mathrm{O}_{2}$ to eliminate endogenous peroxidase activity. They were subsequently incubated overnight with anti-BrdU antibody (ABCys, Paris, France) and diluted 1/200 in PBST-1\% bovine serum albumin at room temperature. Sections were then washed by three rinses in PBST and incubated in a biotinylated secondary rabbit antirat IgG (1/250, Vector Laboratories, Burlingame, CA) for $90 \mathrm{~min}$ followed by amplification with an avidin horseradish peroxidase diluted $1 / 200$ in PBST (Vector Laboratories). Visualization of bound peroxidase was achieved by a reaction in a solution of $50 \mathrm{mM}$ Tris- $\mathrm{HCl}(\mathrm{pH} 7.6)$ containing $0.003 \% \mathrm{H}_{2} \mathrm{O}_{2}, 0.8 \% \mathrm{NiCl}_{2}$, and $0.02 \%$ diaminobenzidine. Every twelfth section throughout the hippocampus was processed for BrdU immunohistochemistry. All BrdU-labeled 
cells in the granule cell layer were counted in each section by an experimenter blinded to the identity of the sections and data were collected with the help of mapping software (Mercator Pro, Explora Nova, La Rochelle, France), coupled to a Zeiss microscope (Axioskop 20, Zeiss, Lena, Germany). A cell was counted as being in the subgranular zone (SGZ) of the DG if it was located in a $40 \mu \mathrm{m}$ wide band immediately adjacent to the surface of the DG granule cell layer. The total number of BrdU-labeled cells per section was determined and multiplied by 12 to obtain the total estimated number of cells per DG. Ten sections were examined per animal $(n=7-$ 8 rats per group). We used the protocol of Kuhn et al. (1996) to assess cell proliferation in the subventricular zone (SVZ). BdrU-labeled cells were counted in the walls of the lateral ventricles on four sections of SVZ per brain taken between 9.4 and $8.8 \mathrm{~mm}$ from bregma and the total number of BrdUlabeled cells was counted and expressed per SVZ and per section.

\section{OBX and Assessment of Hyperlocomotion}

Bilateral OBX was performed in rats anaesthetized with chloral hydrate $(400 \mathrm{mg} / \mathrm{kg}$ i.p.) and mounted in a stereotaxic frame. The head was shaved and a midline sagittal incision was made. Bilateral burr holes ( $2 \mathrm{~mm}$ diameter) were drilled at $7 \mathrm{~mm}$ anterior to bregma and $\pm 2.5 \mathrm{~mm}$ lateral from midline and olfactory bulbs were removed by suction with a vacuum pump attached to a Pasteur pipette. The cavities were then packed with hemostatic sponges (Bloxang, Bausch and LombLaboratoires Chauvin, France) and the wound was closed with sterile suture. Sham-operated rats were treated similarly, with the exception that olfactory bulbs were not removed. After surgery, animals were injected $5 \mathrm{ml}$ i.p. with $5 \%$ glucose. The animals were allowed to recover for 14 days following surgery during which they were handled daily to eliminate any aggressiveness that may have otherwise arisen (Song and Leonard, 2005).

After recovery, rats were daily injected (between 08:30 and 10:30) for 7 days with SB-269970 (2 mg/kg per day, i.p.), 7 or 21 days with fluoxetine $(10 \mathrm{mg} / \mathrm{kg}$ per day, i.p.), or with the vehicle (water). A 5-min open-field test was conducted $24 \mathrm{~h}$ after the last drug injection (ie, 22 and 36 days after bulbectomy, respectively). The open-field chamber consisted of a square wooden box $\left(85 \times 85 \times 70 \mathrm{~cm}^{3}\right)$. As conditions of very high brightness are crucial to observe the hyperactivity in OBX-rats (Mar et al, 2000; Song and Leonard, 2005), the inner faces of the walls were covered with aluminium foil and illumination was provided by a $75 \mathrm{~W}$ bulb positioned $90 \mathrm{~cm}$ directly over the center of the open field (1700-2000 lux). Each rat was placed into the center of the open field and exploratory activity was monitored by a video camera fixed above the arena and relayed to a computer system. To estimate locomotor activity, the open field was virtually divided into 25 squares of $17 \times 17 \mathrm{~cm}$ and the number of crossed squares was calculated.

\section{Neonatal Exposure to 5-HT Agents}

Female Sprague-Dawley rats with litters (standardized to 10 male pups) of postnatal day 1 were purchased. From their arrival, litters were randomly assigned to receive either fluoxetine $(10 \mathrm{mg} / \mathrm{kg})$, SB-269970 $(2 \mathrm{mg} / \mathrm{kg})$, or AS19
$(5 \mathrm{mg} / \mathrm{kg})$. Corresponding to their group, rat pups were given i.p. injections from days P8 to P21 of either drug or an equivalent volume of saline twice daily. As previously described, behavioral testing in the FST and the open field was conducted at 2 months of age (Hansen et al, 1997; Ansorge et al, 2004).

\section{Statistical Analysis}

Electrophysiological data were expressed as percentage of baseline values \pm SEM. Behavioral results were presented as mean \pm SEM. In all experiments, statistical differences between the groups were analyzed with Student's $t$ test or with one-way ANOVA or two-way ANOVA repeated measures followed by the post-hoc PLSD Fisher's test. Differences were considered to be statistically significant when $p$ values were less than 0.05 .

\section{RESULTS}

\section{Effect of 5-HT 7 Receptor Antagonist in the Open-Field Test and the FST}

In a first set of experiments, the illuminated open-field test was used to assess the effect of $5-\mathrm{HT}_{7}$ receptor blockade on the anxiogenic-like effect of fluoxetine. Analysis of data illustrated in Figure 1 revealed a significant effect of treatment $\left(\mathrm{F}_{3,28}=\right.$ 4.87, $p<0.01$, one-way ANOVA). When compared with vehicle-treated animals, acute administration of fluoxetine induced a $80 \%$ decrease in the number of visits to the center of the open-field apparatus ( $p<0.01$, PLSD Fisher's test), whereas no significant change was observed after acute administration with SB-269970. Interestingly, administration of SB-269970 after fluoxetine counteracted the decrease of the number of visits to the center induced by fluoxetine $(p<0.05$, PLSD Fisher's test). These results demonstrated that fluoxetine, acutely administered, induced an anxiogenic-like effect that was prevented by the $5-\mathrm{HT}_{7}$ receptor antagonist SB-269970.

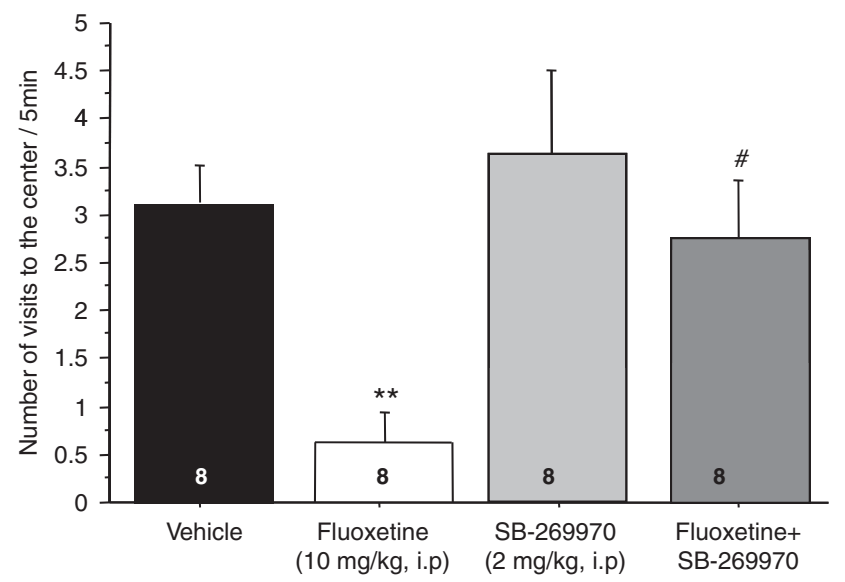

Figure I Effect of the selective $5-\mathrm{HT}_{7}$ antagonist SB-269970 (2 mg/ $/ \mathrm{kg}$, i.p.) and of the SSRI fluoxetine ( $10 \mathrm{mg} / \mathrm{kg}$, i.p. $)$ on the number of visits to the center of an illuminated open-field. Results are expressed as mean \pm SEM. The different compounds were administered 30 or 60 min before the test session. ${ }^{*} * p<0.01$ vs vehicle, ${ }^{\#} p<0.05$ vs fluoxetine; PLSD Fisher's test. The number at the bottom of the columns indicates the number of rats tested. 


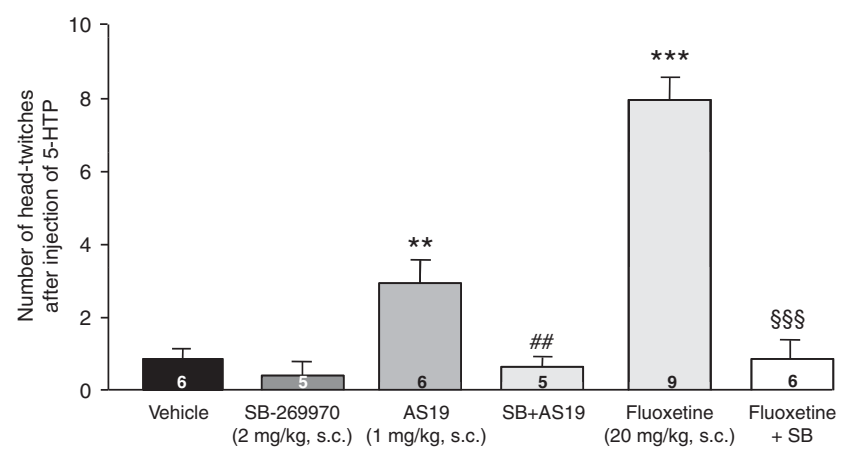

Figure 2 Number of head twitches elicited in 10 min by SB-269970 (2 mg/kg, s.c.) alone or combined with ASI9 (I mg/ $/ \mathrm{kg}$, s.c.) or fluoxetine (20 mg/kg, s.c.) after injection of L-5-HTP $(87.3 \mathrm{mg} / \mathrm{kg}$, s.c.). Results are presented as mean \pm SEM. ${ }^{* *} p<0.0$ I, ${ }^{* * *} p p<0.00$ I vs vehicle; ${ }^{\# \#} p<0.0$ I vs ASI9; $\$ \$ \$ p<0.001$ vs fluoxetine; PLSD Fisher's test. The number at the bottom of the columns indicates the number of rats tested.

In a second set of experiments, the AD potential of SB-269970 was assessed using the FST. As previously shown (Wesołowska and Kowalska, 2008), a sub-acute treatment with the $5-\mathrm{HT}_{7}$ receptor antagonist SB-269970 $(0.5 \mathrm{mg} / \mathrm{kg}$, i.p.) significantly reduced immobility time compared with controls, mean immobility duration in vehicle and SB-269970-treated rats: $73 \pm 8 \mathrm{~s}(n=19)$ and $48 \pm 6 \mathrm{~s}(n=15)$, respectively $\left(\mathrm{t}_{32}=2.34\right.$, $p<0.05$; Student's $t$ test). SB-269970 (0.5 mg/kg, i.p.) did not, however, alter locomotion (mean locomotor activity in vehicle and SB-269970-treated rats: $49 \pm 7$ crossovers/10 min $(n=6)$ and $52 \pm 7$ crossovers $/ 10 \min (n=6)$, respectively $\left(\mathrm{t}_{10}=-0.22\right.$, $p>0.05$; Student's $t$ test)). Hence, these results suggest that SB269970 produced an antidepressant-like profile that was not attributable to an increase in locomotor activity.

\section{Effect of 5-HT 7 Receptor Manipulation on Head-Twitches Responses Induced by L-5-HTP}

Analysis of 5-HTP-induced HTR showed a significant effect of treatment $\left(\mathrm{F}_{5,31}=39.61, p<0.0001\right.$, one-way ANOVA; Figure 2). The number of HTR following an injection of L-5-HTP ( $87.3 \mathrm{mg} / \mathrm{kg}$, s.c.) was significantly enhanced by 3.5 fold in AS19-injected rats ( $1 \mathrm{mg} / \mathrm{kg}$, s.c., $p<0.01$, PLSD Fisher's test). SB-269970 (2 mg/kg, s.c.) by itself had no significant effect on the number of 5-HTP-induced HTR, but abolished the enhancing action of AS19 ( $p<0.01$, PLSD Fisher's test). As reported in previous studies, the SSRI fluoxetine $(20 \mathrm{mg} / \mathrm{kg}$, s.c.) potentiated the head-twitch behavior evoked by 5-HTP ( $>10$ fold; $p<0.001$, PLSD Fisher's test). Interestingly, SB-269970 completely blocked the enhancement of HTR following fluoxetine administration $(p<0.001$, PLSD Fisher's test). These results therefore indicate that $5-\mathrm{HT}_{7}$ receptor blockade did not facilitate the motoric component of the 5-HT syndrome but prevented the potentiating effect of fluoxetine.

\section{Modulation of Dorsal Raphe Nucleus 5-HT Neuronal Firing Activity by 5-HT 7 Receptors}

The effect of cumulative $(2.5-10 \mathrm{mg} / \mathrm{kg})$ intravenous injections of the $5-\mathrm{HT}_{7}$ receptor agonist AS19 in controls and rats pre-injected with the selective $5-\mathrm{HT}_{7}$ receptor antagonist SB-269970 (0.1 mg/kg, i.v.) and with the SSRI fluoxetine (10 mg/kg per day, i.p, 15 days) are illustrated in Figure 3. These data showed significant effects of treatment $\left(\mathrm{F}_{2,12}=11.65 ; p<0.01\right)$, AS19 doses $\left(\mathrm{F}_{2,24)}=5.66 ; p<0.01\right)$, and a treatment $\mathrm{x}$ AS19 dose interaction $\left(\mathrm{F}_{(4,24)}=10.34\right.$; $p<0.0001$; two-way ANOVA with repeated measures). Post-hoc PLSD Fisher's test revealed that dose-response curves of both SB-269970 and fluoxetine-treated rats were significantly different from that of the control rats $(p<0.05$; Figure $3 c$ ). Typical examples showing the reduction of the spontaneous firing activity of 5-HT induced by cumulative doses of AS19 in the vehicle-treated rats and the prevention of this suppressant effect in rats previously injected with SB-269970 are shown in Figure $3 a$ and b. These results indicate that $5-\mathrm{HT}_{7}$ receptors negatively modulated DRN 5-HT neurons activity and that long-term treatment with fluoxetine desensitized these receptors.

\section{A 1-Week Regimen of the 5- $\mathrm{HT}_{7}$ Receptor Antagonist SB-269970 did not Alter DRN 5-HT Neuronal Firing Activity but Enhanced the Tonic Activation of Postsynaptic 5-HT $\mathrm{H}_{1 \mathrm{~A}}$ Receptors in the Hippocampus}

It has been demonstrated that chronic administration of SSRIs, such as fluoxetine or citalopram, induces a robust decrease of 5-HT neuronal activity that is followed by a full recovery, with a delay that corresponds to the onset of their therapeutic effects. Analysis of DRN 5-HT spontaneous firing showed a significant effect of treatment $\left(\mathrm{F}_{2,119}=\right.$ $16.81, p<0.0001$, one-way ANOVA). As expected, a 1-week regimen of the SSRI fluoxetine $(10 \mathrm{mg} / \mathrm{kg}$ per day, i.p.) significantly decreased by $63 \%$ the spontaneous firing activity of 5-HT neurons ( $p<0.001$, PLSD Fisher's test, Figure 4a). This neuronal activity was not, however, modified by a 1-week regimen of SB-269970 (2 mg/kg per day) in comparison with controls (Figure 4a). It is assumed that the recovery of the firing rate of 5-HT neurons after chronic SSRIs is due to $5-\mathrm{HT}_{1 \mathrm{~A}}$ receptor desensitization (Chaput et al, 1986; Le Poul et al, 1995; Czachura and Rasmussen, 2000). In order to assess the sensitivity of presynaptic $5-\mathrm{HT}_{1 \mathrm{~A}}$ autoreceptors after a 1-week regimen of SB-269970, the capacity of the SSRI paroxetine $(0.5 \mathrm{mg} / \mathrm{kg}$, i.v.) to inhibit DRN 5-HT neurons firing activity was examined in vehicle- and SB-269970-treated rats. This probe was deemed optimal to assess the responsiveness of $5-\mathrm{HT}_{1 \mathrm{~A}}$ autoreceptors because it is devoid of $5-\mathrm{HT}_{7}$ affinity and its inhibitory effect is not dependent on $5-\mathrm{HT}_{1 \mathrm{~A}}$ receptors on a cortical-raphe feedback loop involved in inhibiting 5-HT neuron firing (Blier and de Montigny, 1987). Paroxetine $(0.5 \mathrm{mg} / \mathrm{kg}$, i.v.) completely suppressed the firing activity of DRN 5-HT neurons in control rats, whereas it reduced this parameter by only $29 \%$ in rats pre-injected with SB-269970 $\left(n=5\right.$ rats per group, Student's $t$-test; $\left.t_{8}=3.2 ; p<0.05\right)$. These results suggest that a 1-week regimen of SB-269970 produced an early desensitization of $5-\mathrm{HT}_{1 \mathrm{~A}}$ and/or $5-\mathrm{HT}_{7}$ receptors. In addition, it has been previously reported that clinically effective ADs induced an augmentation of the tonic stimulation of inhibitory postsynaptic $5-\mathrm{HT}_{1 \mathrm{~A}}$ receptors (Haddjeri et al, 1998a, b). As most CA3 hippocampal pyramidal neurons are not spontaneously active under chloral hydrate anesthesia, an ejection current of quisqualate ( 0 to $-2 \mathrm{nA}$ ) is necessary to activate them (Haddjeri et al, 1998a, b, 2000; El Mansari et al, 2005; Lucas et al, 2007). The 

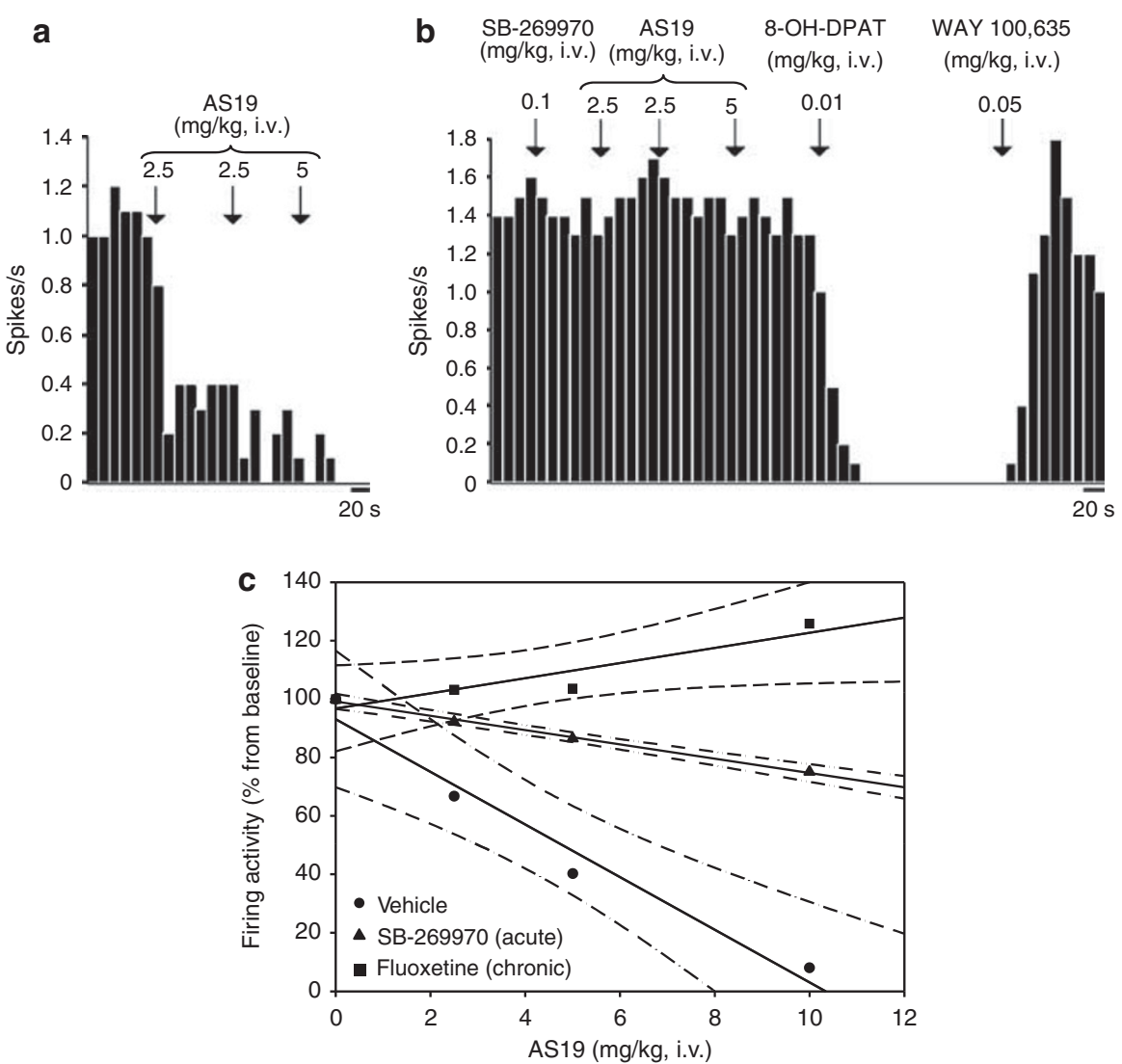

Figure 3 Examples of integrated firing histograms of dorsal raphe 5-HT neurons showing the effect of ASI9 (2.5-10 mg/ $/ \mathrm{kg}$, i.v.) alone in control rats (a) or preinjected with SB-269970 (b). Dose-response curves (solid lines) illustrating the effect of cumulative intravenous doses of ASI9 on dorsal raphe nucleus (DRN) $5-\mathrm{HT}$ neuron average of firing rate, expressed as percentage of basal activity, in controls $(n=5)$, in rats pre-treated with SB- $269970(0.1 \mathrm{mg} / \mathrm{kg}$, i.v., $n=5)$ and in rats chronically treated with fluoxetine ( $10 \mathrm{mg} / \mathrm{kg}$ per day, i.p., 15 days, $n=4)$. Dashed lines depict the $95 \%$ confidence interval of the regression (c).

effect of WAY 100635 was then assessed in control and drug-treated rats (Figure 4b). WAY 100635 slightly increased the quisqualate-activated firing activity of CA3 pyramidal neurons within a dose range of $50-100 \mu \mathrm{g} / \mathrm{kg}$ (i.v.) in controls but more potently in drug-treated rats. A two-way ANOVA with repeated measures revealed a significant effect of treatment $\left(\mathrm{F}_{(2,14)}=4.34 ; p<0.05\right)$, WAY 100635 doses $\left(\mathrm{F}_{(3,42)}=13.06 ; p<0.0001\right)$, and treatment $\mathrm{x}$ WAY 100635 dose interaction $\left(\mathrm{F}_{(6,42)}=3.33 ; p<0.01\right)$. Post-hoc PLSD Fisher's tests revealed that dose-response curves for both SB-269970 and fluoxetine treated rats were significantly different from that of the control rats $(p<0.05$, Figure 4b). Hence, a 1-week treatment with SB-269970 and fluoxetine induced a facilitation of 5-HT neurotransmission, as correlated by an enhanced $5-\mathrm{HT}_{1 \mathrm{~A}}$-mediated inhibitory tone on CA3 pyramidal neurons.

\section{A 1-Week Regimen of SB-269970, but not with Fluoxetine, Promoted Rat Hippocampal Cell Proliferation}

It is now widely accepted that, despite the variety of their pharmacological profiles, a common feature of ADs is their ability to enhance hippocampal cell proliferation. Hence, it has been suggested that assessing an increase of this parameter might be a useful paradigm to screen compounds with AD activity. Thus, the ability of SB-269970 to enhance such cell proliferation was investigated. The examination of hippocampal sections showed that BrdU-positive nuclei in both control and drug-treated rats were restricted in the subgranular cell layer (SGZ) of the DG at the border between the granule cell layer and hilus, and appeared in irregular shapes as clusters of 2-3 cells (Figure 5a). Analysis of data obtained in the SGZ of control and treated rats revealed a significant effect of treatment $\left(\mathrm{F}_{2,19}=3.79\right.$; $p<0.05$, one-way ANOVA). Interestingly, as illustrated in Figure 5b, a 1-week regimen of SB-269970 (2 mg/kg per day, i.p.) significantly enhanced the number of BrdU-positive cells in the SGZ of the DG by $41 \%$ when compared with controls $(p<0.05$, PLSD Fisher's test), whereas no significant effect was observed after a 7-day regimen of the SSRI fluoxetine $(10 \mathrm{mg} / \mathrm{kg}$ per day, i.p.). Moreover, this enhancement was specific to hippocampal cell proliferation as neither SB-269970 nor fluoxetine affected the number of newborn cells in the SVZ of the olfactory bulb (Figure $5 \mathrm{c}$; $\mathrm{F}_{2,17}=0.53 ; p>0.05$, one-way ANOVA). Altogether, these results showed that the $5-\mathrm{HT}_{7}$ receptor antagonist promoted cell proliferation selectively in the SGZ of the DG of the hippocampus, more promptly than with SSRIs. In order to determine that the effect of SB-269970 on cell proliferation was mediated through the 5-HT system, the inhibitor of 5-HT synthesis, PCPA, was administered to control and 

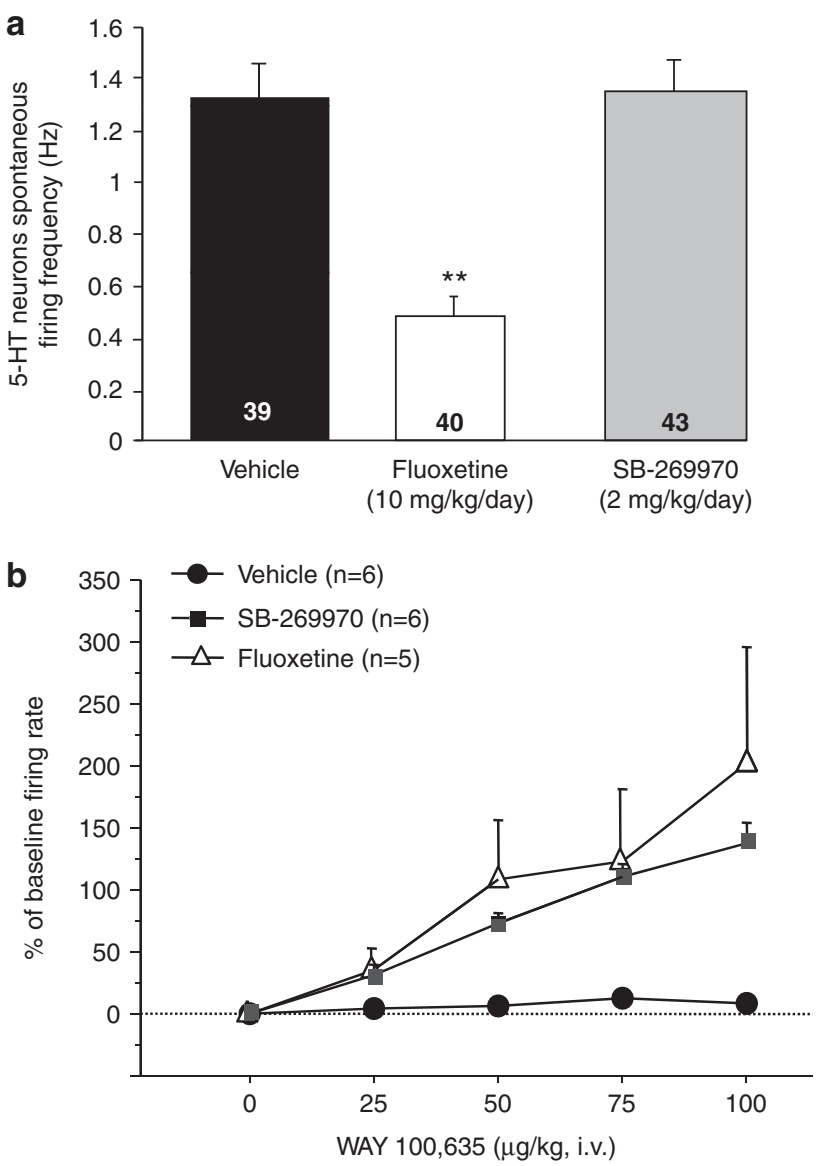

Figure 4 (a) Histograms representing the spontaneous firing rate of dorsal raphe 5-HT neurons (expressed in $\mathrm{Hz}$ ) in rats administered the vehicle, fluoxetine (10 mg/kg per day, i.p.) or SB-269970 (2 mg/kg per day, i.p.) for 7 days. The number at the bottom of each column indicates the number of neurons recorded. $* * *+0.01$ vs vehicle. (b) Effect of cumulative intravenous doses of the selective 5-HT IA antagonist WAY 100635 on the average (mean \pm SEM) of firing activity of hippocampal pyramidal neurons of the CA3 sub-field, in rats administered i.p. SB-269970 (2 mg/kg per day, $n=6)$, fluoxetine $(10 \mathrm{mg} / \mathrm{kg}$ per day, 7 days, $n=5)$ or the vehicle $(n=7)$.

SB-269970 pre-treated rats. As illustrated in Figure 5d, a statistical difference was found when groups were compared using one-way ANOVA $\left(\mathrm{F}_{2,18}=4.41 ; p<0.05\right)$. Data obtained for the SGZ of rats exposed to PCPA alone ( $100 \mathrm{mg} / \mathrm{kg}$ per day for 4 days, i.p.) showed that the number of newborn cells in the SGZ was decreased by $54 \%$ compared with controls ( $p<0.05$, PLSD Fisher's test). Interestingly, in rats receiving regimen of SB-269970 for 1 week, the enhancement of cell proliferation in the SGZ previously obtained was no longer present after PCPA, as evidenced by the significant $42 \%$ decrease compared with controls ( $p<0.05$, PLSD Fisher's test). These results suggest that a functional 5-HT system is necessary for SB-269970 to exert its effect on hippocampal cell proliferation.

\section{Effects of Treatment with SB-269970 or Fluoxetine in OBX Rats}

It had previously been reported that OBX rats exhibit locomotor hyperactivity that is suppressed after long-term antidepressant treatment. The effect of SB-269970 was thus investigated on this behavioral parameter. Analysis of data illustrated in Figure 6a revealed a significant effect of treatment $\left(\mathrm{F}_{2,15}=10.55 ; p<0.01\right.$, one-way ANOVA $)$. As expected, OBX rats that received the vehicle for 7 days displayed a strong increase $(+135 \%)$ of locomotor activity when placed in the open field in comparison with the shamoperated animals ( $p<0.001$, PLSD Fisher's test). Interestingly, a 1-week treatment with SB-269970 ( $2 \mathrm{mg} / \mathrm{kg}$ per day, i.p.) significantly reduced this hyperlocomotion $(p<0.05$, PLSD Fisher's test). In contrast, the OBX-fluoxetine-treated rats (7 days, $10 \mathrm{mg} / \mathrm{kg}$ per day, i.p.) still exhibited a strong hyperactivity compared with the sham-operated animals ( $+121 \% ; p<0.05$; PLSD Fisher's test performed after a global one-way ANOVA $\left(\mathrm{F}_{2,15}=5.84 ; p<0.05\right)$, Figure $\left.6 \mathrm{~b}\right)$. Only a 3-week treatment with fluoxetine was able to reverse the OBX-induced hyperactivity $(p<0.001$; PLSD Fisher's test performed after a global one-way ANOVA $\left(\mathrm{F}_{2,15}=\right.$ 11.25; $p<0.01$ ), Figure 6c)). This suggests that SB-269970 had a faster antidepressant-like action than fluoxetine.

\section{Neonatal Exposure to SB-269970 or AS19 had no Detectable Effects in Adulthood}

In neonatal rodents, sustained administration of 5-HT ADs (including SSRIs and tricyclic antidepressants) during the early life period from postnatal 8 (PN8) to PN21 results in a pattern of maladaptive behaviors that are evident and persistent in adulthood (Mirmiran et al, 1981; Maudhuit et al, 1995; Hansen et al, 1997; Ansorge et al, 2004). These behavioral changes include alterations in locomotor activity and increased immobility in the FST (Mirmiran et al, 1981; Hilakivi and Hilakivi, 1987; Alexandre et al, 2006; Hansen et al, 1997). The effect of postnatal exposure to fluoxetine (10 mg/kg per day for 14 days, i.p.), SB-269970 (2 mg/kg per day for 14 days, i.p.), or with AS19 (5 mg/kg per day for 14 days, i.p.) was examined in adulthood (Figure 7). A significant effect of treatment $\left(\mathrm{F}_{3,40}=3.01 ; p<0.05\right.$, oneway ANOVA) was obtained. In comparison with control animals, rats neonatally exposed to the SSRI fluoxetine exhibited a $58 \%$ decrease in the number of visits to the center of the open-field apparatus $(p<0.05$, PLSD Fisher's test). No significant difference was observed after neonatal exposure to SB-269970 or AS19 (Figure 7a). These results showed an increase in anxiety-like behavior by postnatal exposure to the SSRI fluoxetine, but not with the $5-\mathrm{HT}_{7}$ receptor agonist or the antagonist. In the FST, a significant effect of treatment was observed $\left(\mathrm{F}_{3,34}=5.35\right.$; $p<0.01$, oneway ANOVA). The immobility duration was significantly enhanced by $32 \%$ in fluoxetine-exposed rats $(p<0.05$, PLSD Fisher's test) during the neonatal period, but not in AS19or SB-269970-exposed animals (Figure 7b). Taken together, these results showed that neonatal exposure to the SSRI fluoxetine, but not to AS19 or SB-269970, produced anxietyand depression-like behaviors in early adulthood of the rats.

\section{DISCUSSION}

The present results show that behavioral, electrophysiological and neuro-anatomical changes that usually correlate with the onset of beneficial action of long-term treatment 

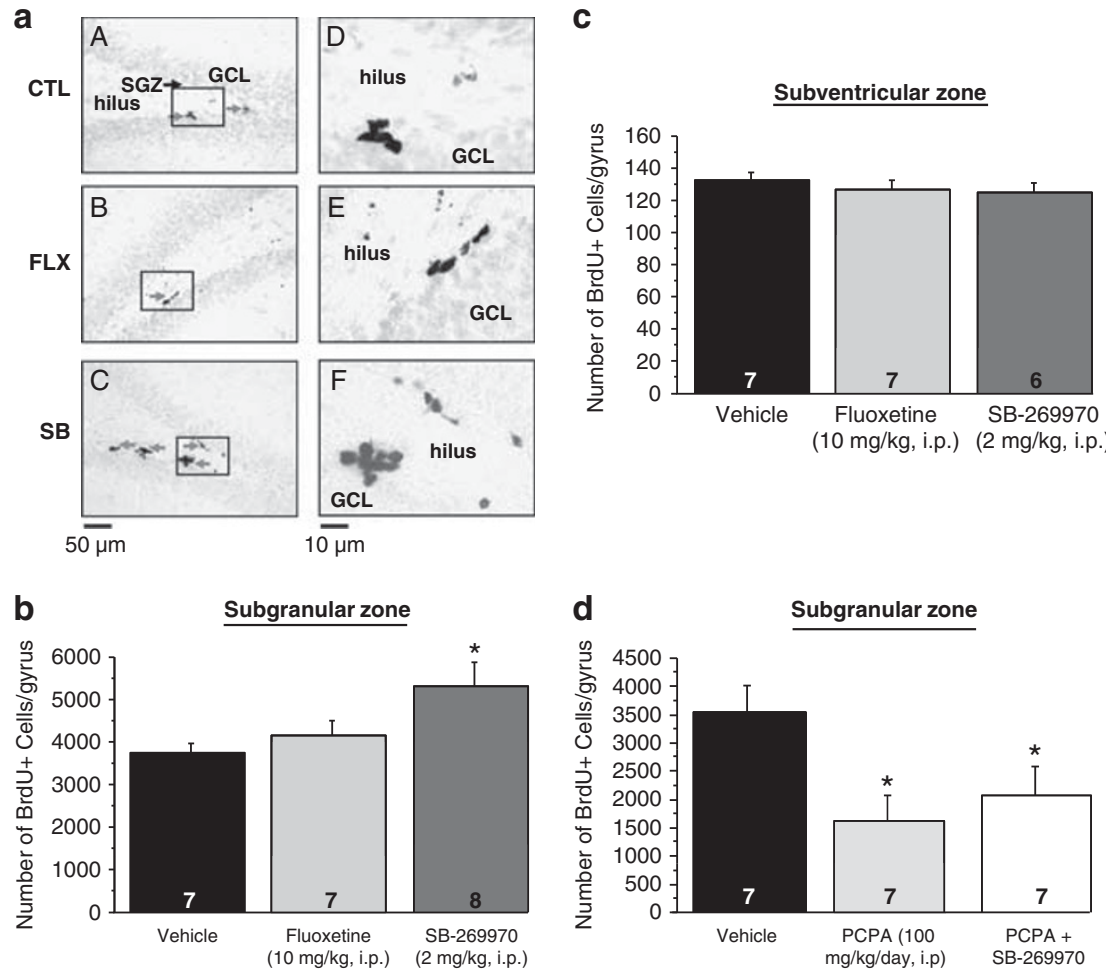

Figure 5 Effect of SB-269970 (2 mg/kg per day, 7 days) and fluoxetine ( $10 \mathrm{mg} / \mathrm{kg}$ per day, 7 days) on the number of BrdU-positive cells in the sub-ventricular zone (SVZ) and the sub-granular zone (SGZ) of the hippocampus. (a) Photomicrographs (magnification: $\times 10$ and $\times 50$ for the small rectangles) representative of the vehicle (CTL), fluoxetine (FLX), and SB-269970 (SB) groups. Please note the clusters of positive cells found in the presence of SB-269970 (small rectangles). (b, c, d) show the summary (mean \pm SEM) of the effects of SB-269970 and fluoxetine in the sub-ventricular zone, the SGZ of the hippocampus and the SGZ of 5-HT depleted rats with PCPA, respectively. The quantification of BrdU-labeled cells was performed $24 \mathrm{~h}$ after the last injection of BrdU. GCL, granule cell layer. *p $<0.05$ vs vehicle, PLSD Fisher's test.

with SSRIs are already observed after only 7 days of treatment with the $5-\mathrm{HT}_{7}$ receptor antagonist SB-269970.

The first results showed that SB-269970 reduced immobility in the FST without modifying locomotor activity. These data confirm previous results showing an antidepressant-like action of SB-269970 in the same test, with doses ranging from 1.25 to $2.5 \mathrm{mg} / \mathrm{kg}$ (Wesołowska and Kowalska, 2008). This group reported that an intrahippocampal injection of SB-269970 also reduces immobility time, suggesting that the hippocampus is one of the brain structures involved in the beneficial action of $5-\mathrm{HT}_{7}$ antagonism (Wesolowska et al, 2006). It has also been reported that both pharmacological inhibition and genetic inactivation of $5-\mathrm{HT}_{7}$ receptors induce antidepressant-like behavior in the mouse tail suspension test (Hedlund et al, 2005; Bonaventure et al, 2007; Sarkisyan et al, 2010), as well as an antianxiety effect in the Vogel drinking test in rats, the elevated plus maze in rats, and in the four-plate test in mice (Wesolowska et al, 2006). Interestingly, a dose of $2 \mathrm{mg} / \mathrm{kg}$ of SB-269970 had no detectable effect in the present study by itself, suggesting a lack of modification of 5-HT release as previously shown (Bonaventure et al, 2007), it counteracted the anxiogenic-like effect of acute administration of fluoxetine in the illuminated open field (Figure 1). Previous reports have shown that the SSRIs fluoxetine and citalopram display anxiogenic behaviors via the activation of 5$\mathrm{HT}_{2 \mathrm{C}}$ receptors as their effects were prevented by a 5- $\mathrm{HT}_{2 \mathrm{C}}$ antagonist (Burghardt et al, 2007; Dekeyne et al, 2000; Greenwood et al, 2008). Hence, it can be suggested that an enhanced activation of $5-\mathrm{HT}_{2} \mathrm{C}$, and also of $5-\mathrm{HT}_{7}$, receptors might be a mechanism for the anxiogenic effects of SSRIs observed initially during treatment, based on the present results. These findings are of particular interest as several atypical antipsychotics, such as amisulpride and aripiprazole, which are potent $5-\mathrm{HT}_{7}$ antagonist, are used in the treatment of mood disorders (Smeraldi, 1998; Montgomery, 2002; Na et al, 2008: Berman et al, 2009). Additionally, Abbas et al. (2009) demonstrated that, in contrast to their wild-type littermates, $5-\mathrm{HT}_{7}$ receptor knock-out mice did not respond to amisulpride in the FST and the tail suspension test. This indicates that $5-\mathrm{HT}_{7}$ receptor antagonism may underly, at least in part, the antidepressant-like actions of antipsychotics such as amisulpride and aripiprazole (Abbas et al, 2009; Sarkisyan et al, 2010). Taken together, these data suggest that $5-\mathrm{HT}_{7}$ receptor antagonists are of potential interest for the treatment of both depression and anxiety.

Another acute action of $5-\mathrm{HT}_{7}$ receptor manipulation was tested in the 5-HTP-induced HTR paradigm. The increase of monoamine contents in brain, especially 5 -HT, is known to cause several abnormal behaviors in animals, such as HTR and head-weaving (Kim et al, 1998). It is also reported that $\mathrm{HTR}$ is induced by $5-\mathrm{HT}_{2 \mathrm{~A}}$ receptor stimulation in the prefrontal cortex (Willins and Meltzer, 1997; GonzálezMaeso et al, 2003; Nakagawasai et al, 2004; Moya et al, 2007). It was documented for the first time that $5-\mathrm{HT}_{7}$ receptor stimulation is also able to produce HTR (Figure 2). This effect was, however, smaller in amplitude than that 

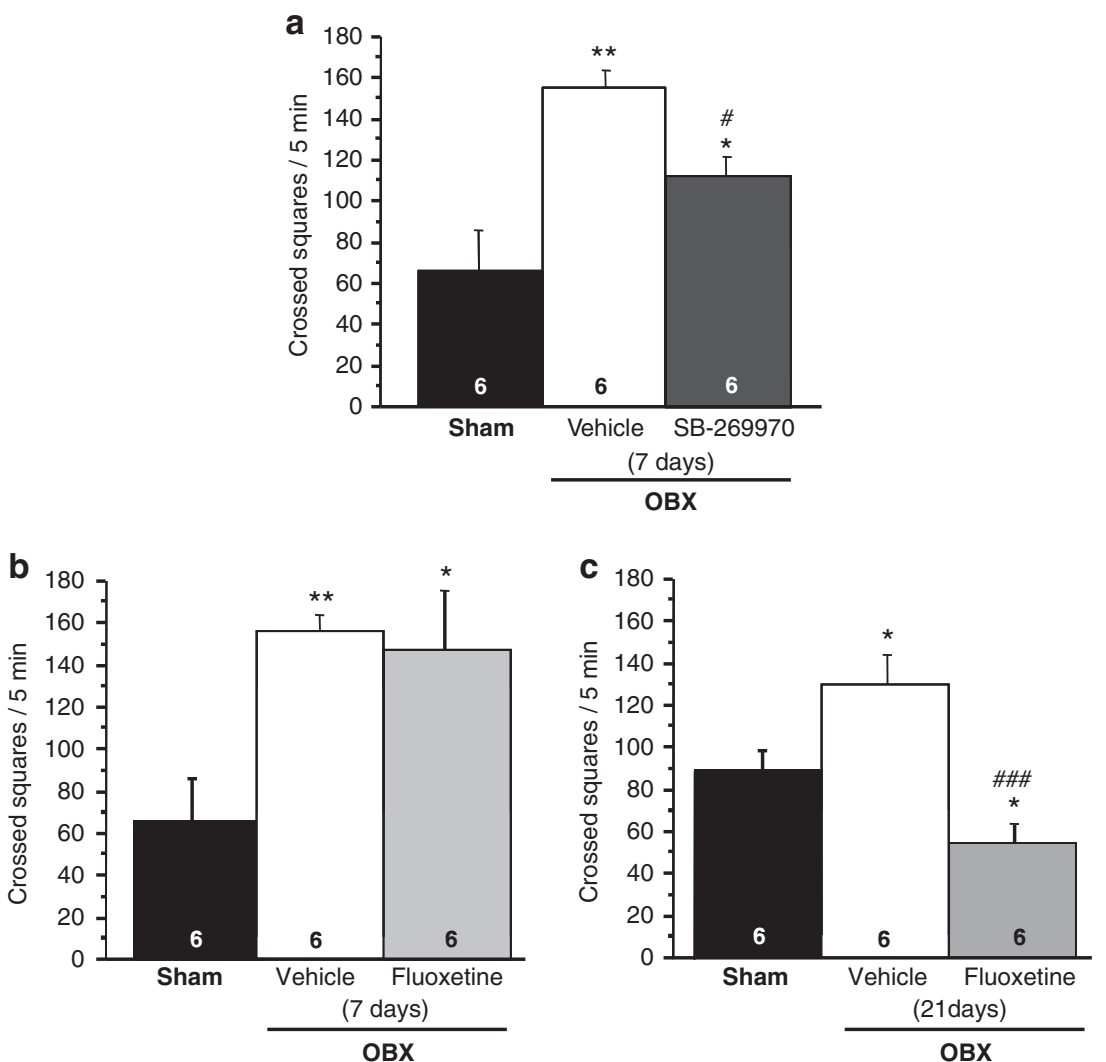

Figure 6 Effect of SB-269970 (2 mg/kg per day i.p., 7 days) (a) and fluoxetine (I $0 \mathrm{mg} / \mathrm{kg}$ per day i.p.) 7 (b) or 21 days (c) on the locomotor activity of olfactory bulbectomized (OBX) rats. The OBX surgery was performed (see Materials and Methods section for more details), and rats were allowed to recover for a period of I4 days. SB-269970 and fluoxetine were then administered and locomotion was measured in an open-field apparatus after 7 and 21 days of drug treatment. Results represent the mean $\left( \pm\right.$ SEM) values of six animals per group. ${ }^{*} p<0.05, * * p<0.01$ vs sham, \# $p<0.05$, \#\#\# $p<0.00$ I vs OBX-Vehicle; PLSD Fisher's test.

produced by fluoxetine, suggesting that the increase of cerebral 5-HT level induced by fluoxetine and 5-HTP activates a larger number of 5-HT receptors to induce HTR. Similarly, several studies have previously shown that ADs including SSRIs (citalopram, escitalopram, and fluoxetine) and monoamine oxidase inhibitors (tranylcypromine, pargyline) potentiate the 5-HTP-induced behavioral syndrome (Ortmann et al, 1980; Shimomura et al, 1981; Hyttel et al, 1992; Stórustovu et al, 2004; Sánchez and Kreilgaard, 2004). Notably, the 5- $\mathrm{HT}_{7}$ receptor antagonist SB-269970 did not modify the 5-HTP-induced HTR but prevented both the AS19- and fluoxetine-stimulating effects. Interestingly, various drugs with $5-\mathrm{HT}_{7}$ antagonistic activity, including atypical antipsychotics olanzapine and risperidone, antagonize HTR induced by 5-HTP or tryptamine (Kitaichi et al, 1994; Fu et al, 2000; Van Oekelen et al, 2002).

The present study also showed that raphe-hippocampus 5 - HT transmission can be markedly modified by $5-\mathrm{HT}_{7}$ receptor blockade. Indeed, acute activation of $5-\mathrm{HT}_{7}$ receptors by AS19 suppressed the firing activity of all 5-HT neurons recorded in DRN and SB-269970 prevented this effect (Figure 3), suggesting that $5-\mathrm{HT}$ firing activity is under negative $5-\mathrm{HT}_{7}$ receptor control. This uniform responsiveness of 5-HT neurons stands in contrast with the observation that $5-\mathrm{HT}_{4}$ receptor agonists, which have been proposed to be fast acting ADs, activate only a subpopulation of 5-HT neurons (Lucas et al, 2007). In addition, the present data showed that the $5-\mathrm{HT}_{7}$ receptor antagonists
SB-269970 and DR-4365 prevented the inhibition of DRN 5-HT firing activity caused by the SSRIs paroxetine and fluvoxamine, respectively (see Supplementary Figure S1 in the Supplementary Material). Such a result fits well with the potentiating action of SB-269970 on 5-HT release, the antidepressant-like behavior, and REM sleep suppression induced by the SSRI citalopram (Bonaventure et al, 2007). The control of DRN neuronal activity by $5-\mathrm{HT}_{7}$ receptors seems to be indirect and it has been suggested that $5-\mathrm{HT}_{7}$ receptors are not been localized directly on 5-HT neurons but rather on GABAergic and/or glutamatergic neurons (Harsing et al, 2004; Monti et al, 2008). On the other hand, in rats chronically treated with the SSRI fluoxetine, the selective $5-\mathrm{HT}_{7}$ agonist AS-19 no longer suppressed $5-\mathrm{HT}$ firing activity, suggesting a desensitization of $5-\mathrm{HT}_{7}$ receptors. As previously shown (Czachura and Rasmussen, 2000), a 7-day treatment with fluoxetine decreases DRN 5-HT firing activity, in agreement with previous studies using different SSRIs (Chaput et al, 1986; de Montigny et al, 1990). This decrease is attributable to an increased level of extracellular 5-HT (Bel and Artigas, 1992; Yoshioka et al, 1995; Bonaventure et al, 2007) that leads to a greater activation of 5- $\mathrm{HT}_{1 \mathrm{~A}}$ autoreceptors (Blier et al, 1984; Chaput et al, 1986; Le Poul et al, 1995; Haddjeri et al, 1998a). A full recovery is usually reported after about 2 or 3 weeks treatment with classical SSRIs (Chaput et al, 1986; de Montigny et al, 1990; Czachura and Rasmussen, 2000), a time course consistent with their delayed therapeutic 
a

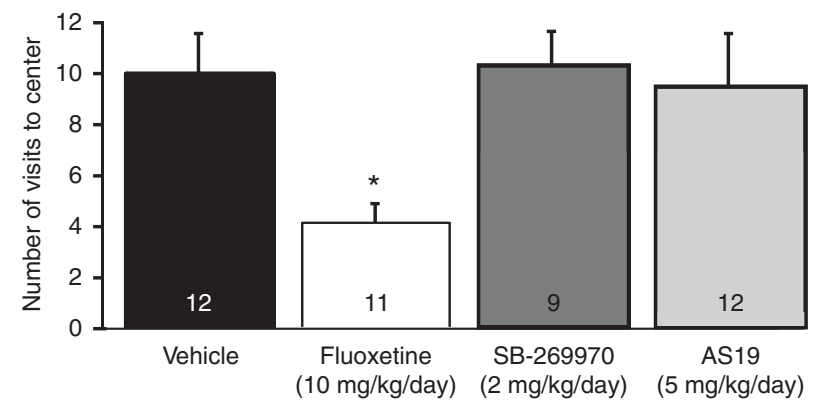

b

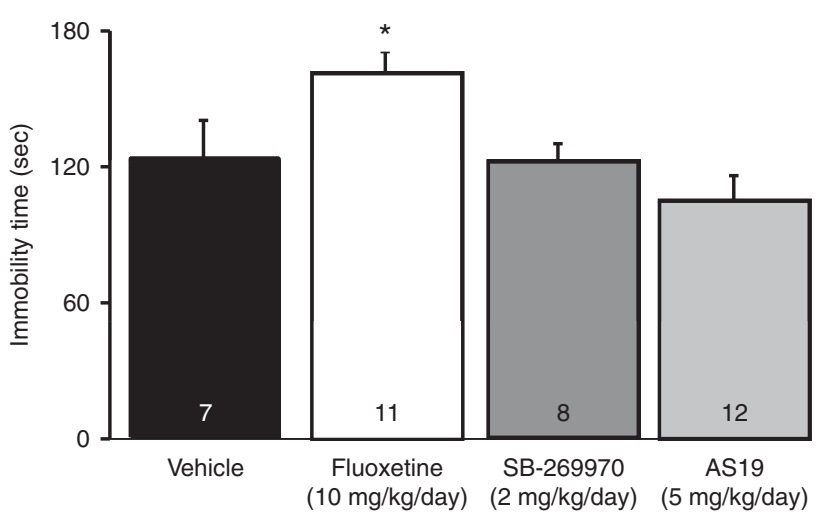

Figure 7 Effect of early life repeated administrations of fluoxetine, SB-269970, and ASI9 on the anxiety- and depressive-like behaviors in adulthood. (a) Compared with vehicle-treated animals, rats neonatally treated with the SSRI fluoxetine $(10 \mathrm{mg} / \mathrm{kg}$ per day for 14 days, i.p.) displayed lower number of visits to the center in the open-field apparatus whereas no difference was observed after a neonatal treatment with SB269970 (2 mg/ $/ \mathrm{kg}$ per day for 14 days, i.p.), or with ASI 9 ( $5 \mathrm{mg} / \mathrm{kg}$ per day for 14 days, i.p.). (b) In the FST, the immobility duration was significantly enhanced in fluoxetine-exposed rats during the neonatal period, but not in rats administered with SB-269970 or AS19. ${ }^{*} p<0.05$ vs vehicle, PLSD Fisher's test.

effect (Blier and de Montigny, 1999; Lanfumey and Hamon, 2004). The recovery of the firing rate is believed to be due to a desensitization of the somatodendritic $5-\mathrm{HT}_{1 \mathrm{~A}}$ autoreceptors of 5-HT neurons in DRN (Blier and de Montigny, 1994). Importantly, 5-HT firing activity was not modified after 7 days of SB-269970 administration, but acute injection of paroxetine failed to induce a complete suppression of the 5-HT firing activity, indicating a desensitization of these $5-\mathrm{HT}_{1 \mathrm{~A}}$ autoreceptors. Hence, a reduced $5-\mathrm{HT}_{1 \mathrm{~A}}$ and/or $5-\mathrm{HT}_{7}$ receptor responsiveness in the DRN after $5-\mathrm{HT}_{7}$ receptor blockade takes place in a faster manner than most ADs. This desensitization may be secondary to an early increase of the extracellular 5-HT levels after only a 7-day treatment with SB-269970. This would be consistent with an enhancement of 5-HT transmission in projection areas such as the dorsal hippocampus after 1 week of SB 269970 administration. In fact, this enhancement was shown by the manifestation of an enhanced inhibitory tone on postsynaptic $5-\mathrm{HT}_{1 \mathrm{~A}}$ receptors, as the selective antagonist WAY 100635 was able to increase CA3 pyramidal neuron activity (Figure 4). Such an effect was reported using classical ADs after 2 to 3 weeks of treatment (Haddjeri et al, 1998b; Besson et al, 2000; El Mansari et al, 2005, Lucas et al, 2007). However, it was observed that fluoxetine was also effective after a 1-week treatment. Hence, a sub-acute treatment with this SSRI may be sufficient to induce a disinhibition of CA3 pyramidal neurons in dorsal hippocampus, but not a recovery of 5-HT neuronal activity in DRN. Then, both desensitization of $5-\mathrm{HT}_{1 \mathrm{~A}}$ autoreceptors and increased tonus on hippocampal postsynaptic 5-HT receptors may be necessary to induce detectable $\mathrm{AD}$ effects.

The current findings on $5-\mathrm{HT}_{1 \mathrm{~A}}$ neurotransmission are in line with the fact that a 1-week treatment with SB-269970, but not fluoxetine, promoted specifically the proliferation rate in the DG of hippocampus (Figure 5). This result brings additional support to the idea that $5-\mathrm{HT}_{7}$ receptor antagonists display a fast antidepressant-like profile. In fact, such progenic effect was previously observed after only long-term (2 to 3 weeks) treatment with various ADs including fluoxetine (Malberg et al, 2000; Santarelli et al, 2003; Malberg and Duman, 2003; Mnie-Filali et al, 2007b). To our knowledge, only non-selective $5-\mathrm{HT}_{7}$ receptors antagonists (such as atypical neuroleptics risperidone or clozapine) were used to assess the effects on hippocampal cell proliferation but the results were not conclusive (Halim et al, 2004; Kodama et al, 2004; Schmitt et al, 2004). Also, Sarkisyan and Hedlund (2009) reported that the rate of cell proliferation in the DG was identical in $5-\mathrm{HT}_{7}$ receptor wild-type and knock-out mice even if such mice present antidepressant-like phenotypes (Guscott et al, 2005; Hedlund et al, 2005). As it has been recently proposed (Bessa et al, 2009), neuronal plasticity (dendritic remodeling and synaptic contacts) in the hippocampus, rather than neurogenesis itself, could be responsible for the latter behavioral phenotypes of $5-\mathrm{HT}_{7}$ mutant mice. Interestingly, the stimulation of hippocampal cell proliferation induced by SB-269970 was prevented by PCPA exposure, in line with previous studies showing a robust decline in hippocampal proliferation rate following PCPA exposure (Banasr et al, 2001; Jha et al, 2006). Hence, the present results suggest that the stimulating effect of $5-\mathrm{HT}_{7}$ receptor antagonism on cell proliferation in hippocampus necessitates an intact 5-HT system, and is not mediated by a direct action of SB-269970.

As previously discussed, SB-269970 produced an AD effect in the FST. Despite the fact that FST is a useful, highthroughput, and reliable test, classical ADs such as fluoxetine produce a response after only 2 days of treatment, which is inconsistent with their delayed therapeutic action. It is therefore difficult to determine if SB-269970 has a more rapid onset of action in comparison with these ADs based on this test. To address this issue, we used OBX rats, which require long-term (2-3 weeks) treatment to observe an AD-like response (McGrath and Norman, 1998; Song and Leonard, 2005). An exaggeration of locomotor activity in OBX animals was observed compared with sham rats when placed in a high illuminated open-field (Figure 6). This is consistent with previous reports and is believed to be due to a deficit of habituation to a new stressful environment (Cairncross et al. 1979; Van Riezen and Leonard, 1990; McNish and Davis, 1997; Song and Leonard, 2005; Romeas et al, 2009). Importantly, although fluoxetine was ineffective after a 7-day treatment (as expected for an SSRI; Lucas et al, 2007; Breuer et al, 2007), SB-269970 reversed the OBXinduced hyperactivity. This is the first report of a rapid effect of $5-\mathrm{HT}_{7}$ receptor antagonist in a 'chronic' behavioral 
model of depression. The faster effect of SB-269970 in the OBX paradigm is an important indication of the $5-\mathrm{HT}_{7}$ receptor antagonists as putative fast-acting ADs.

Finally, the profile of $5-\mathrm{HT}_{7}$ receptor antagonists was tested on neonatal AD exposure paradigm. Neonatal administration of ADs (such as clomipramine, citalopram, or fluoxetine) to rodents during the early life period (from PN8 to PN21) was shown to produce a constellation of maladaptive behaviors, possibly related to anxiety and depression, that persist in adulthood (Vogel et al, 1988; Andersen et al, 2002; Ansorge et al, 2004; Maciag et al, 2006; Popa et al, 2008). In this study, postnatal exposure to the SSRI fluoxetine significantly decreased visits to an openfield center in adulthood while increasing total immobility time in the FST, in agreement with previous reports (Ansorge et al, 2004; Karpova et al, 2009; Popa et al, 2010). $5-\mathrm{HT}_{1 \mathrm{~A}}$ receptors have been proposed to have a crucial role in the mediation of such a deleterious action of SERT blockade (Alexandre et al, 2006; Popa et al, 2008). The use of preferential 5-HT receptor agonists in this paradigm also indicated the involvement of other 5-HT receptor subtypes. Indeed, early life stimulation of $5-\mathrm{HT}_{1 \mathrm{~B}}, 5-\mathrm{HT}_{2 \mathrm{~A}}$, $5-\mathrm{HT}_{2 \mathrm{C}}$, and $5-\mathrm{HT}_{4}$ receptors induced a significant decrease in the number of visits in the open-field center (see Supplementary Figure S2 in the Supplementary Material). In contrast, such behavioral disturbances were not observed after a neonatal administration of AS19 or SB-269970.

Overall, the multiple experimental approaches used herein provided important support for the hypothesis that $5-\mathrm{HT}_{7}$ receptor antagonists may act as $\mathrm{AD}$ agents with a rapid onset of action. Thus far, only one $5-\mathrm{HT}_{7}$ receptor antagonist has been assessed in a clinical trial for moderate to severe depression (JNJ-18038683; Johnson and Johnson Pharmaceutical Research and Development). It is hoped that the present results will further stimulate the development of selective $5-\mathrm{HT}_{7}$ receptor antagonists as a novel and potentially improved class of ADs.

\section{ACKNOWLEDGEMENTS}

We acknowledge the kindness and the helpful advices of Dr Guy Debonnel, deceased 04 November, 2006. The technical assistance from Wilfried Lebon and Davy VidonButhion was greatly appreciated. This research was supported by University Claude Bernard Lyon 1 and the CNRS.

\section{DISCLOSURE}

Dr Blier has received research grants, honoraria for advisory board and speaking engagements from Astra Zeneca, Bristol Myers Squibb, Janssen, Pfizer, Merck Squibb, Merck, Labopharm, Servier, and Eli Lilly and Dr Haddjeri has received research grants from Lundbeck and Solvay. The others authors declare no conflict of interest.

\section{REFERENCES}

Abbas AI, Hedlund PB, Huang XP, Tran TB, Meltzer HY, Roth BL (2009). Amisulpride is a potent 5-HT7 antagonist: relevance for antidepressant actions in vivo. Psychopharmacology 205: $119-128$.
Aghajanian GK, Vandermaelen CP (1982). Intracellular recordings from serotonergic dorsal raphe neurons: pacemaker potentials and the effect of LSD. Brain Res 238: 463-469.

Alexandre C, Popa D, Fabre V, Bouali S, Venault P, Lesch KP et al (2006). Early life blockade of 5-hydroxytryptamine 1A receptors normalizes sleep and depression-like behavior in adult knockout mice lacking the serotonin transporter. J Neurosci 26: 5554-5564.

Andersen SL, Dumont NL, Teicher MH (2002). Differences in behavior and monoamine laterality following neonatal clomipramine treatment. Dev Psychobiol 41: 50-57.

Ansorge MS, Zhou M, Lira A, Hen R, Gingrich JA (2004). Early-life blockade of the 5-HT transporter alters emotional behavior in adult mice. Science 306: 879-881.

Banasr M, Hery M, Brezun JM, Daszuta A (2001). Serotonin mediates oestrogen stimulation of cell proliferation in the adult dentate gyrus. Eur J Neurosci 14: 1417-1424.

Bel N, Artigas F (1992). Fluvoxamine preferentially increases extracellular 5-hydroxytryptamine in the raphe nuclei: an in vivo microdialysis study. Eur J Pharmacol 229: 101-103.

Berman RM, Fava M, Thase ME, Trivedi MH, Swanink R, McQuade RD et al (2009). Aripiprazole augmentation in major depressive disorder: a double-blind, placebo-controlled study in patients with inadequate response to antidepressants. CNS Spectr 14: 197-206.

Bessa JM, Ferreira D, Melo I, Marques F, Cerqueira JJ, Palha JA et al (2009). The mood-improving actions of antidepressants do not depend on neurogenesis but are associated with neuronal remodeling. Mol Psychiatry 14: 764-773.

Besson A, Haddjeri N, Blier P, de Montigny C (2000). Effects of the combination of mirtazapine and paroxetine on the 5-HT neurotransmission. Eur Neuropsychopharmacol 10: 177-188.

Blier P, de Montigny C, Tardif D (1984). Effects of the two antidepressant drugs mianserin and indalpine on the serotonergic system: single-cell studies in the rat. Psychopharmacology (Berl) 84: 242-249.

Blier P, de Montigny C (1987). Modification of 5-HT neuron properties by sustained administration of the 5-HT1A agonist gepirone: electrophysiological studies in the rat brain. Synapse 1: 470-480.

Blier P, de Montigny C (1994). Current advances and trends in the treatment of depression. Trends Pharmacol Sci 15: 220-226.

Blier P, de Montigny C (1999). Serotonin and drug-induced therapeutic responses in major depression, obsessive-compulsive and panic disorders. Neuropsychopharmacology 21: 91S-98S.

Bonaventure P, Kelly L, Aluisio L, Shelton J, Lord B, Galici R et al (2007). Selective blockade of 5-hydroxytryptamine (5-HT)7 receptors enhances 5-HT transmission, antidepressant-like behavior, and rapid eye movement sleep suppression induced by citalopram in rodents. J Pharmacol Exp Ther 321: 690-698.

Breuer ME, Groenink L, Oosting RS, Westenberg HG, Olivier B (2007). Long-term behavioral changes after cessation of chronic antidepressant treatment in olfactory bulbectomized rats. Biol Psychiatry 61: 990-995.

Burghardt NS, Bush DE, McEwen BS, LeDoux JE (2007). Acute selective serotonin reuptake inhibitors increase conditioned fear expression: blockade with a 5-HT(2C) receptor antagonist. Biol Psychiatry 62: 1111-1118.

Cairncross KD, Wren A, Forster C, Cox B, Schnieden H (1979). The effect of psychoactive drugs on plasma corticosterone levels and behaviour in the bulbectomized rat. Pharmacol Biochem Behav 10: $355-359$.

Castrén E (2004). Neurotrophic effects of antidepressant drugs. Curr Opin Pharmacol 4: 58-64.

Chaput Y, Blier P, de Montigny C (1986). In vivo electrophysiological evidence for the regulatory role of autoreceptors on serotonergic terminals. J Neurosci 6: 2796-2801. 
Czachura JF, Rasmussen K (2000). Effects of acute and chronic administration of fluoxetine on the activity of serotonergic neurons in the dorsal raphe nucleus of the rat. Naunyn Schmiedebergs Arch Pharmacol 362: 266-275.

Dekeyne A, Denorme B, Monneyron S, Millan MJ (2000). Citalopram reduces social interaction in rats by activation of serotonin (5-HT)(2C) receptors. Neuropharmacology 39: 1114-1117.

de Montigny C, Chaput Y, Blier P (1990). Modification of serotonergic neuron properties by long-term treatment with serotonin reuptake blockers. J Clin Psychiatry 51(Suppl B): 4-8.

Duman RS, Nakagawa S, Malberg J (2001). Regulation of adult neurogenesis by antidepressant treatment. Neuropsychopharmacology 25: 836-844.

El Mansari M, Sánchez C, Chouvet G, Renaud B, Haddjeri N (2005). Effects of acute and long-term administration of escitalopram and citalopram on serotonin neurotransmission: an in vivo electrophysiological study in rat brain. Neuropsychopharmacology 30: 1269-1277.

Faure C, Mnie-Filali O, Haddjeri N (2006a). Long-term adaptive changes induced by serotonergic antidepressant drugs. Expert Rev Neurother 6: 235-245.

Faure C, Mnie-Filali O, Scarna H, Debonnel G, Haddjeri N (2006b). Effects of the 5-HT7 receptor antagonist SB-269970 on rat hormonal and temperature responses to the 5-HT1A/7 receptor agonist 8-OH-DPAT. Neurosci Lett 404: 122-126.

Fu Y, Zhu ZT, Chen LJ, Yu LP, Jin GZ (2000). Behavioral characteristics of olanzapine: an atypical neuroleptic. Acta Pharmacol Sin 21: 329-334.

González-Maeso J, Yuen T, Ebersole BJ, Wurmbach E, Lira A, Zhou $\mathrm{M}$ et al (2003). Transcriptome fingerprints distinguish hallucinogenic and nonhallucinogenic 5-hydroxytryptamine $2 \mathrm{~A}$ receptor agonist effects in mouse somatosensory cortex. J Neurosci 23: 8836-8843.

Greenwood BN, Strong PV, Brooks L, Fleshner M (2008). Anxietylike behaviors produced by acute fluoxetine administration in male Fischer 344 rats are prevented by prior exercise. Psychopharmacology (Berl) 199: 209-222.

Guscott M, Bristow LJ, Hadingham K, Rosahl TW, Beer MS, Stanton JA et al (2005). Genetic knockout and pharmacological blockade studies of the 5-HT7 receptor suggest therapeutic potential in depression. Neuropharmacology 48: 492-502.

Haddjeri N, Blier P (1995). Pre- and post-synaptic effects of the 5-HT3 agonist 2-methyl-5-HT on the 5-HT system in the rat brain. Synapse 20: 54-67.

Haddjeri N, Blier P, de Montigny C (1998a). Long-term antidepressant treatments result in a tonic activation of forebrain 5-HT1A receptors. J Neurosci. 18: 10150-10156.

Haddjeri N, de Montigny C, Curet O, Blier P (1998b). Effects of sustained administration of the reversible monoamine oxidase-A inhibitor befloxatone on the 5-HT neurotransmission. Eur J Pharmacol 343: 179-192.

Haddjeri N, Faure C, Lucas G, Mnie-Filali O, Chouvet G, Astier B et al (2004). In-vivo modulation of central 5-hydroxytryptamine (5-HT1A) receptor-mediated responses by the cholinergic system. Int J Neuropsychopharmacol 7: 391-399.

Haddjeri N, Szabo ST, de Montigny C, Blier P (2000). Increased tonic activation of rat forebrain 5-HT(1A) receptors by lithium addition to antidepressant treatments. Neuropsychopharmacology 22: 346-356.

Halim ND, Weickert CS, McClintock BW, Weinberger DR, Lipska BK (2004). Effects of chronic haloperidol and clozapine treatment on neurogenesis in the adult rat hippocampus. Neuropsychopharmacology 29: 1063-1069.

Hansen HH, Sánchez C, Meier E (1997). Neonatal administration of the selective serotonin reuptake inhibitor Lu 10-134-C increases forced swimming-induced immobility in adult rats: a putative animal model of depression? J Pharmacol Exp Ther 283: 1333-1341.
Harsing Jr LG, Prauda I, Barkoczy J, Matyus P, Juranyi Z (2004). A 5HT7 heteroreceptor-mediated inhibition of $[3 \mathrm{H}]$ serotonin release in raphe nuclei slices of the rat: evidence for a serotonergicglutamatergic interaction. Neurochem Res 29: 1487-1497.

Hedlund PB, Kelly L, Mazur C, Lovenberg T, Sutcliffe JG, Bonaventure P (2004). 8-OH-DPAT acts on both 5-HT1A and 5-HT7 receptors to induce hypothermia in rodents. Eur $J$ Pharmacol 487: 125-132.

Hedlund PB (2009). The 5-HT7 receptor and disorders of the nervous system: an overview. Psychopharmacology (Berl) 206: 345-354.

Hedlund PB, Huitron-Resendiz S, Henriksen SJ, Sutcliffe JG (2005). 5-HT7 receptor inhibition and inactivation induce antidepressant-like behavior and sleep pattern. Biol Psychiatry 58: 831-837.

Hedlund PB, Sutcliffe JG (2004). Functional, molecular and pharmacological advances in 5-HT7 receptor research. Trends Pharmacol Sci 25: 481-486.

Hensler JG (2002). Differential regulation of 5-HT1A receptor-G protein interactions in brain following chronic antidepressant administration. Neuropsychopharmacology 26: 565-573.

Hilakivi LA, Hilakivi I (1987). Increased adult behavioral 'despair' in rats neonatally exposed to desipramine or zimeldine: an animal model of depression? Pharmacol Biochem Behav 28: 367-369.

Hyttel J, Bøges $\varnothing$ KP, Perregaard J, Sánchez C (1992). The pharmacological effect of citalopram residues in the (S)-(+)enantiomer. J Neural Transm Gen Sect 88: 157-160.

Jha S, Rajendran R, Davda J, Vaidya VA (2006). Selective serotonin depletion does not regulate hippocampal neurogenesis in the adult rat brain: differential effects of $\mathrm{p}$-chlorophenylalanine and 5,7-dihydroxytryptamine. Brain Res 1075: 48-59.

Kandel ER, Spencer WA (1961). Electrophysiology of hippocampal neurons. II. After potentials and repetitive firing. J Neurophysiol 24: 243-259.

Karpova NN, Lindholm J, Pruunsild P, Timmusk T, Castrén E (2009). Long-lasting behavioural and molecular alterations induced by early postnatal fluoxetine exposure are restored by chronic fluoxetine treatment in adult mice. Eur Neuropsychopharmacol 19: 97-108.

Kim HS, Park IS, Park WK (1998). NMDA receptor antagonists enhance 5-HT2 receptor-mediated behavior, head-twitch response, in mice. Life Sci 63: 2305-2311.

Kitaichi K, Yamada K, Hasegawa T, Furukawa H, Nabeshima T (1994). Effects of risperidone on phencyclidine-induced behaviors: comparison with haloperidol and ritanserin. Jpn J Pharmacol 66: 181-189.

Kodama M, Fujioka T, Duman RS (2004). Chronic olanzapine or fluoxetine administration increases cell proliferation in hippocampus and prefrontal cortex of adult rat. Biol Psychiatry 56: 570-580.

Kuhn HG, Dickinson-Anson H, Gage FH (1996). Neurogenesis in the dentate gyrus of the adult rat: age-related decrease of neuronal progenitor proliferation. J Neurosci 16: 2027-2033.

Lanfumey L, Hamon M (2004). 5-HT1 receptors. Curr Drug Targets CNS Neurol Disord 3: 1-10.

Laplante P, Diorio J, Meaney MJ (2002). Serotonin regulates hippocampal glucocorticoid receptor expression via a 5-HT7 receptor. Brain Res Dev Brain Res 139: 199-203.

Le Poul E, Laaris N, Doucet E, Laporte AM, Hamon M, Lanfumey L (1995). Early desensitization of somato-dendritic 5-HT1A autoreceptors in rats treated with fluoxetine or paroxetine. Naunyn Schmiedebergs Arch Pharmacol 352: 141-148.

Lucas G, Rymar VV, Du J, Mnie-Filali O, Bisgaard C, Manta S et al (2007). Serotonin (5-HT(4)) receptor agonists are putative antidepressants with a rapid onset of action. Neuron 55: 712-725.

Maciag D, Williams L, Coppinger D, Paul IA (2006). Neonatal citalopram exposure produces lasting changes in behavior which are reversed by adult imipramine treatment. Eur J Pharmacol 532: $265-269$. 
Malberg JE, Duman RS (2003). Cell proliferation in adult hippocampus is decreased by inescapable stress: reversal by fluoxetine treatment. Neuropsychopharmacology 28: 1562-1571.

Malberg JE, Eisch AJ, Nestler EJ, Duman RS (2000). Chronic antidepressant treatment increases neurogenesis in adult rat hippocampus. J Neurosci 20: 9104-9110.

Mar A, Spreekmeester E, Rochford J (2000). Antidepressants preferentially enhance habituation to novelty in the olfactory bulbectomized rat. Psychopharmacology (Berl) 150: 52-60.

Maudhuit C, Hamon M, Adrien J (1995). Electrophysiological activity of raphe dorsalis serotoninergic neurones in a possible model of endogenous depression. Neuroreport 6: 681-684.

McGrath C, Norman TR (1998). The effect of venlafaxine treatment on the behavioural and neurochemical changes in the olfactory bulbectomised rat. Psychopharmacology (Berl) 136: 394-401.

McNish KA, Davis M (1997). Olfactory bulbectomy enhances sensitization of the acoustic startle reflex produced by acute or repeated stress. Behav Neurosci 111: 80-91.

Mirmiran M, van de Poll NE, Corner MA, van Oyen HG, Bour HL (1981). Suppression of active sleep by chronic treatment with chlorimipramine during early postnatal development: effects upon adult sleep and behavior in the rat. Brain Res 204: 129-146.

Mnie-Filali O, Faure C, El Mansari M, Lambas-Senas L, Berod A, Zimmer L et al (2007b). R-citalopram prevents the neuronal adaptive changes induced by escitalopram. NeuroReport 18: 1553-1556.

Mnie-Filali O, Lambas-Señas L, Scarna H, Haddjeri N (2009). Therapeutic potential of 5-HT receptors in mood disorders. Curr Drug Targets 10: 1109-1117.

Mnie-Filali O, Lambás-Señas L, Zimmer L, Haddjeri N (2007a). 5-HT7 receptor antagonists as a new class of antidepressants. Drug News Perspect 20: 613-618.

Monti JM, Leopoldo M, Jantos H (2008). The serotonin 5-HT7 receptor agonist LP-44 microinjected into the dorsal raphe nucleus suppresses REM sleep in the rat. Behav Brain Res 191: 184-189.

Montgomery SA (2002). Dopaminergic deficit and the role of amisulpride in the treatment of mood disorders. Int Clin Psychopharmacol 17(Suppl 4): S9-S17.

Moya PR, Berg KA, Gutiérrez-Hernandez MA, Sáez-Briones P, Reyes-Parada M, Cassels BK et al (2007). Functional selectivity of hallucinogenic phenethylamine and phenylisopropylamine derivatives at human 5-hydroxytryptamine (5-HT)2A and 5-HT2C receptors. J Pharmacol Exp Ther 321: 1054-1061.

Mullins UL, Gianutsos G, Eison AS (1999). Effects of antidepressants on 5-HT7 receptor regulation in the rat hypothalamus. Neuropsychopharmacology 21: 352-367.

$\mathrm{Na}$ YH, Hong SH, Lee JH, Park WK, Baek DJ, Koh HY et al (2008). Novel quinazolinone derivatives as 5-HT7 receptor ligands. Bioorg Med Chem 16: 2570-2578.

Nakagawasai O, Arai Y, Satoh SE, Satoh N, Neda M, Hozumi M et al (2004). Monoamine oxidase and head-twitch response in mice. Mechanisms of alpha-methylated substrate derivatives. Neurotoxicology 25: 223-232.

Nestler EJ, Barrot M, DiLeone RJ, Eisch AJ, Gold SJ, Monteggia LM (2002). Neurobiology of depression. Neuron 34: 13-25.

Ortmann R, Waldmeier PC, Radeke E, Felner A, Delini-Stula A (1980). The effects of 5-HT uptake- and MAO-inhibitors on L-5-HTP-induced excitation in rats. Naunyn Schmiedebergs Arch Pharmacol 311: 185-192.

Paxinos G, Watson C (1998). The Rat Brain in Stereotaxic Coordinates, Fourth Edition. Academic Press: New York.

Popa D, Cerdan J, Repérant C, Guiard BP, Guilloux JP, David DJ et al (2010). A longitudinal study of 5-HT outflow during chronic fluoxetine treatment using a new technique of chronic microdialysis in a highly emotional mouse strain. Eur $J$ Pharmacol 628: 83-90.
Popa D, Léna C, Alexandre C, Adrien J (2008). Lasting syndrome of depression produced by reduction in serotonin uptake during postnatal development: evidence from sleep, stress, and behavior. J Neurosci 28: 3546-3554.

Porsolt RD, Bertin A, Jalfre M (1977). Behavioral despair in mice: a primary screening test for antidepressants. Arch Int Pharmacodyn Ther 229: 327-336.

Ranck JB (1975). Behavioral correlates and firing repertoires of neurons in the dorsal hippocampal formation and septum of unrestrained rats In: Isaacson RL, Pribram KH (eds). The Hippocampus. Plenum: New York. pp 207-244.

Romeas T, Morissette MC, Mnie-Filali O, Piñeyro G, Boye SM (2009). Simultaneous anhedonia and exaggerated locomotor activation in an animal model of depression. Psychopharmacology (Berl) 205: 293-303.

Ruat M, Traiffort E, Leurs R, Tardivel-Lacombe J, Diaz J, Arrang JM et al (1993). Molecular cloning, characterization, and localization of a high-affinity serotonin receptor (5-HT7) activating cAMP formation. Proc Natl Acad Sci USA 90: 8547-8551.

Sánchez C, Kreilgaard M (2004). R-citalopram inhibits functional and 5-HTP-evoked behavioural responses to the SSRI, escitalopram. Pharmacol Biochem Behav 77: 391-398.

Santarelli L, Saxe M, Gross C, Surget A, Battaglia F, Dulawa S et al (2003). Requirement of hippocampal neurogenesis for the behavioral effects of antidepressants. Science 301: 805-809.

Sarkisyan G, Hedlund PB (2009). The 5-HT7 receptor is involved in allocentric spatial memory information processing. Behav Brain Res 202: 26-31.

Sarkisyan G, Roberts AJ, Hedlund PB (2010). The 5-HT receptor as a mediator and modulator of antidepressant-like behavior. Behav Brain Res 209: 99-108.

Schmitt A, Weber S, Jatzko A, Braus DF, Henn FA (2004). Hippocampal volume and cell proliferation after acute and chronic clozapine or haloperidol treatment. J Neural Transm 111: $91-100$.

Shimomura K, Mori J, Honda F (1981). Backward walking induced by L-5-hydroxytryptophan in mice. Jpn J Pharmacol 31: 39-46.

Sleight AJ, Carolo C, Petit N, Zwingelstein C, Bourson A (1995). Identification of 5-hydroxytryptamine7 receptor binding sites in rat hypothalamus: sensitivity to chronic antidepressant treatment. Mol Pharmacol 47: 99-103.

Smeraldi E (1998). Amisulpride versus fluoxetine in patients with dysthymia or major depression in partial remission: a doubleblind, comparative study. J Affect Disord 48: 47-56.

Song C, Leonard BE (2005). The olfactory bulbectomised rat as a model of depression. Neurosci Biobehav Rev 29: 627-647.

Stórustovu S, Sánchez C, Pörzgen P, Brennum LT, Larsen AK, Pulis $\mathrm{M}$ et al (2004). R-citalopram functionally antagonises escitalopram in vivo and in vitro: evidence for kinetic interaction at the serotonin transporter. Br J Pharmacol 142: 172-180.

Thomas DR, Melotto S, Massagrande M, Gribble AD, Jeffrey P, Stevens AJ et al (2003). SB-656104-A, a novel selective 5-HT7 receptor antagonist, modulates REM sleep in rats. $\mathrm{Br} J$ Pharmacol 139: 705-714.

To ZP, Bonhaus DW, Eglen RM, Jakeman LB (1995). Characterization and distribution of putative 5-ht7 receptors in guinea-pig brain. Br J Pharmacol 115: 107-116.

Van Oekelen D, Megens A, Meert T, Luyten WH, Leysen JE (2002). Role of 5-HT receptors in the tryptamine-induced 5-HT syndrome in rats. Behav Pharmacol 13: 313-318.

Van Riezen H, Leonard BE (1990). Effects of psychotropic drugs on the behavior and neurochemistry of olfactory bulbectomized rats. Pharmacol Ther 47: 21-34.

Vogel G, Hartley P, Neill D, Hagler M, Kors D (1988). Animal depression model by neonatal clomipramine: reduction of shock induced aggression. Pharmacol Biochem Behav 31: 103-106.

Wesolowska A, Nikiforuk A, Stachowicz K (2006). Potential anxiolytic and antidepressant effects of the selective 5-HT7 


\begin{tabular}{rr} 
Antidepressant-like profile of $\begin{array}{r}\mathbf{5}-\mathbf{H T}_{\mathbf{7}} \text { antagonism } \\
\text { O Mnie-Filali et al }\end{array}$ \\
\hline 1288
\end{tabular}

receptor antagonist SB 269970 after intrahippocampal administration to rats. Eur J Pharmacol 553: 185-190.

Wesołowska A, Kowalska M (2008). Influence of serotonin 5-HT receptor blockade on the behavioral and neurochemical effects of imipramine in rats. Pharmacol Rep 60: 464-474.

Willins DL, Meltzer HY (1997). Direct injection of 5-HT2A receptor agonists into the medial prefrontal cortex produces a head-twitch response in rats. J Pharmacol Exp Ther 282: 699-706.
Yau JL, Noble J, Seckl JR (2001). Acute restraint stress increases 5-HT7 receptor mRNA expression in the rat hippocampus. Neurosci Lett 309: 141-144.

Yoshioka M, Matsumoto M, Numazawa R, Togashi H, Smith CB, Saito $H$ (1995). Changes in the regulation of 5-hydroxytryptamine release by alpha2-adrenoceptors in the rat hippocampus after long-term desipramine treatment. Eur J Pharmacol 294: 565-570.

Supplementary Information accompanies the paper on the Neuropsychopharmacology website (http://www.nature.com/npp) 